\title{
Static Load Test of Foundation Plate and Measuring Their Deformation and Internal Tensions
}

\author{
Vojtěch Buchta* \\ Department of Structures, Faculty of Civil Engineering, VŠB - Technical University Ostrava, 17.listopadu 15/2175, 708 33 \\ Ostrava-Poruba, Czech Republic \\ ${ }^{*}$ Corresponding author
}

\begin{abstract}
Foundation structures of reinforced concrete, testing their properties and modeling their behavior after loading is a wide area to research. Analysis of interaction between the subsoil and the foundation structures has been developed for many years. For the determination of stress in foundation structure is needed to determine the influence of the stiffness respectively pliability of subsoil to structural internal forces, and vice versa, how the stiffness of the foundation structure affects the resulting subsidence. Previous researches on loading of reinforced slabs have shown a number of phenomena significantly influencing their strength and behaviour. However, no general agreement is yet found on a physical theory (either in codes of practice or in design models) suitably describing the interaction between the subsoil and the foundation structures. Our aim is to implement several of experimental measurements, to create numerical models and modify the parameters of numerical models to better fit the facts. It will then be possible to design the foundation structures more efficiently, safer and cheaper.
\end{abstract}

Keywords-static load testing; destructive testing; diagnostic of concrete; foundation slab; interaction between foundation and subsoil

\section{INTRODUCTION}

Experimental measurements described in this paper are a continuation of research focused on interaction of foundation concrete structures and subsoil. In the world are often tested a lot of different structures on the subsoil $[1,2,3]$ and some experiments are carried out in Czech Republic too. This problematic is researching on the Faculty of Civil Engineering VSB - Technical University of Ostrava for long time. It is one of the main research directions at the Department of structures. In this article I would like to describe experimental tests and compare the subsidence and deformation of several different baseboards. $[4,5,6,7,8]$

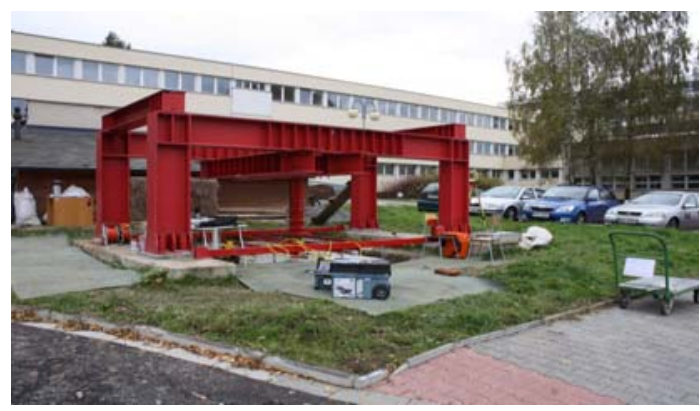

FIGURE I. STEEL TEST EQUIPMENT

\section{EXPERIMENTAL TESTING OF CONCRETE SLAB}

\section{A. Experimental Test Equipment}

The testing stand is intended for static load tests with the maximum press load $1 \mathrm{MN}$. [9] The testing stand is flexible enough for various tests and testing positions. Using the testing stand, it will be possible to test models of the footings, strips, slabs. The size of the models of the foundation structures will be limited by the cross dimension of the testing stand and size of the steel structure subject to the loading. It is possible to change the position of the loading force, the loading surface, and also composition of the subsoil. The basic principle on this equipment is clear from the Fig.1. We adhere to very precise measurement methodology, in order to compare the results of measurements on several samples with one another and also with numerical models.

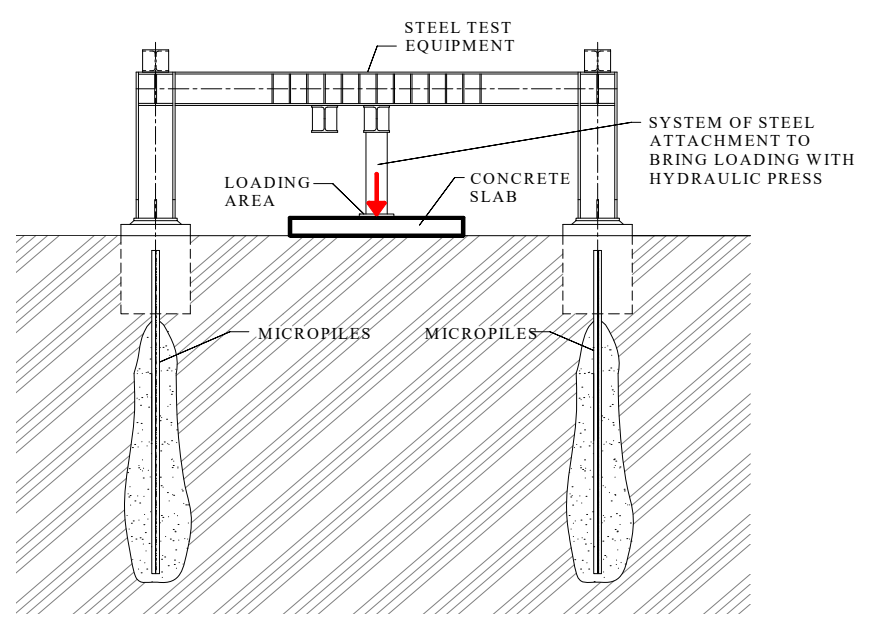

FIGURE II. EXPERIMENTAL TEST EQUIPMENT- SCHEME [16]

\section{B. Subsoil Under Foundation Slab}

Subsoil Under testing equipment consists from clayey soil but It is considerably inhomogeneous. The tests described in this article were still on original ground. Now it is already homogeneous subsoil and into several levels of stress sensors were placed. This will allow to better monitor and compare the stress values in the soil. 

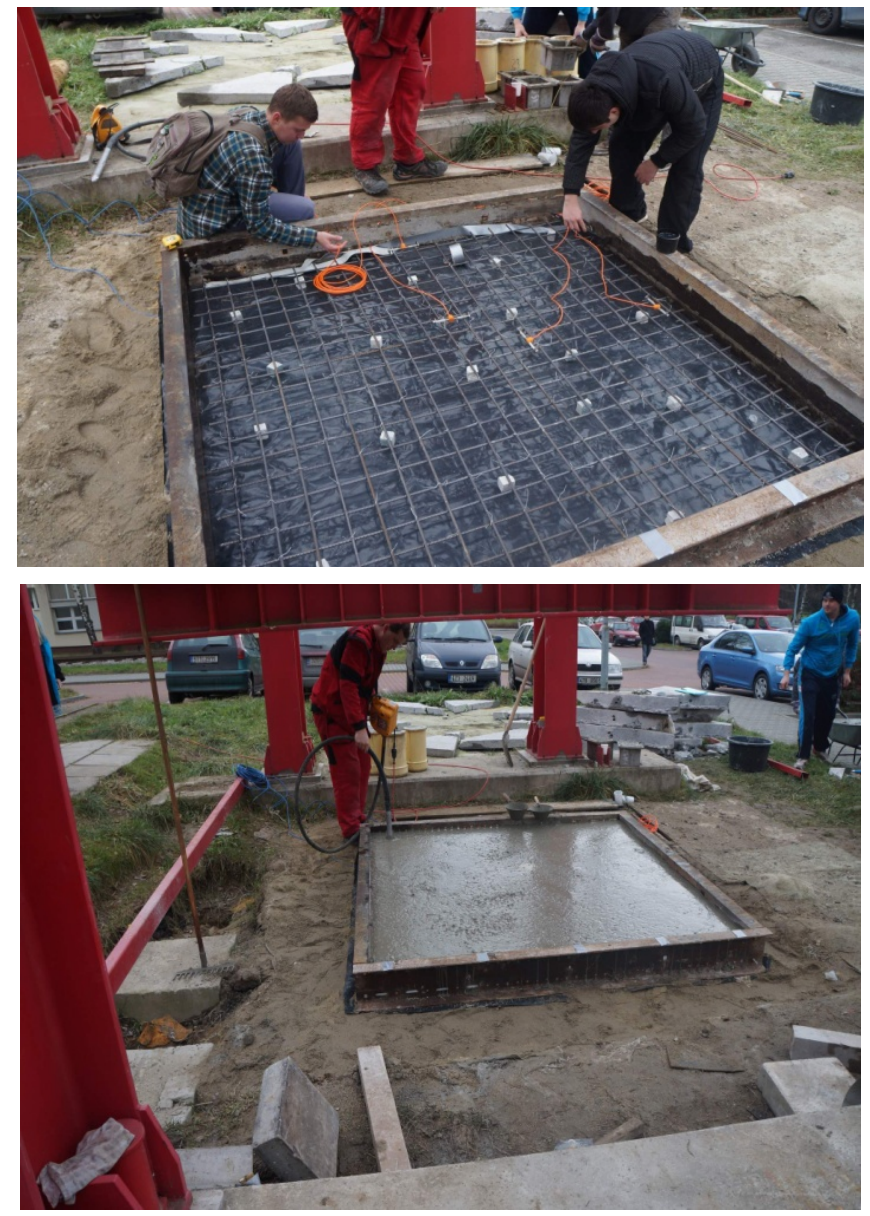

FIGURE III. (A) REINFORCING OF THE SLAB (AND AND IMPLEMENTATION OF INTERNAL STRAIN GAUGES; (B) CONCRETING OF THE TEST SAMPLE.[16]

\section{Reinforced Concrete Slab}

Dimensions of this tile are $2 \times 2 \mathrm{~m}$, its thickness is 0.15 meters, concrete cover is $0.03 \mathrm{~m}$. Was used concrete $\mathrm{C} 35 / 40$. This board is reinforced knotted mesh 8/100/100. Vertical deformation monitored and recorded 16 potenciometric sensors. Tensions within the board monitor and record 4 wire strain gauges.

\section{RESULT FROM THE EXPERIMENTAL MEASUREMENT}

For a load test was chosen fixed intervals loading $75 \mathrm{kN} /$ $30 \mathrm{~min}$. (loading and $30 \mathrm{~min}$. waiting). Loading boards took place over two days. The first day was a plate loaded only on the strength of $750 \mathrm{kN}$ and avoid damage. It is clear from the graph that substantial part of deformation was returnable which means that majority of the test was carried out in elastic area. The next day, the plate was loaded at level $950 \mathrm{kN}(1000 \mathrm{kN}$ is limit load of devices) and in this test were the slab corrupted by punching shear just at the force $950 \mathrm{kN}$.

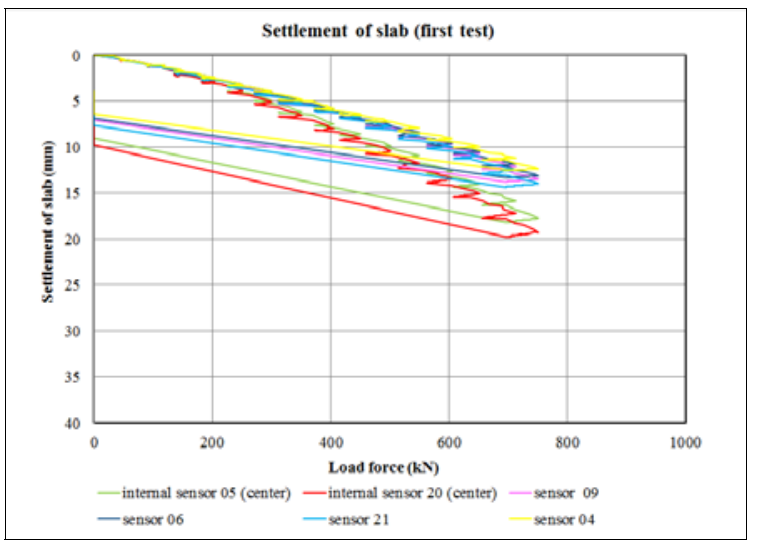

FIGURE IV. SETTLEMENT OF THE SLAB (FIRST TEST).[16]

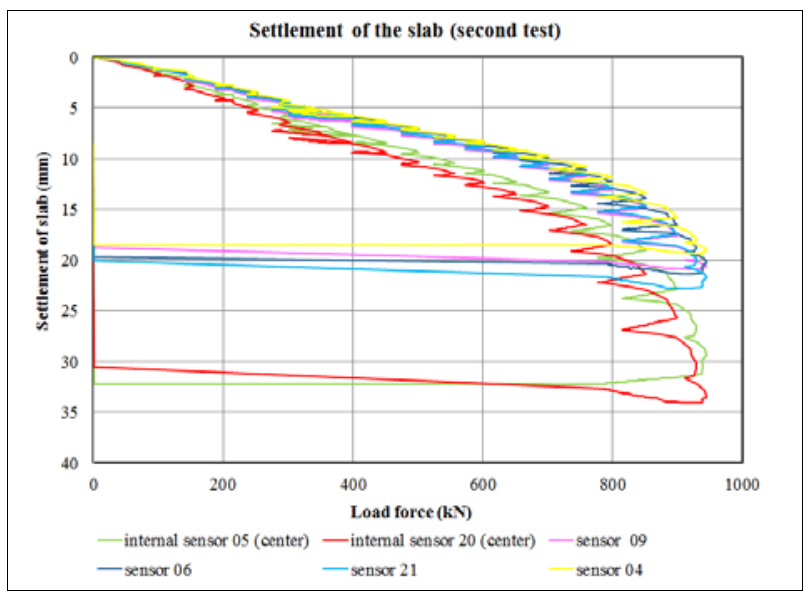

FIGURE V. SETtLEMENT OF THE SLAB (SECOND TEST).[16]
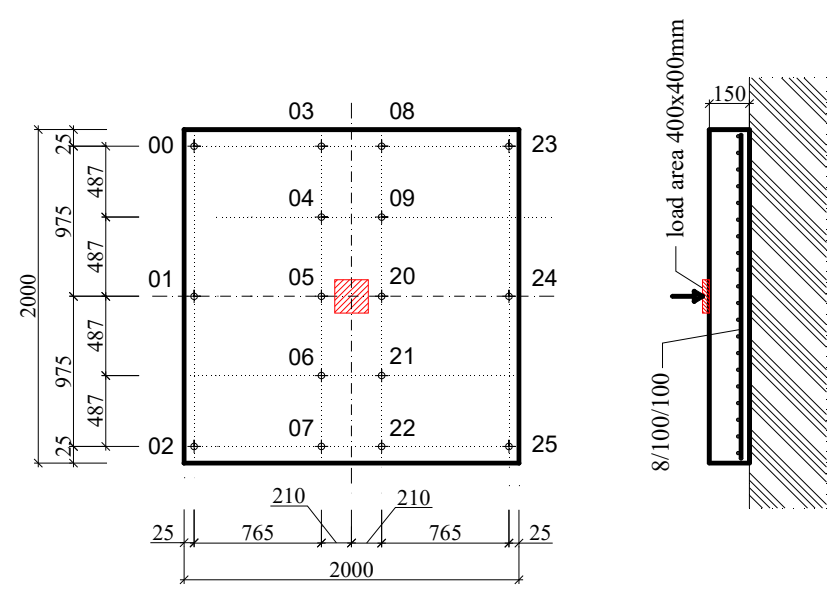

FIGURE VI. STEEL TEST EQUIPMENT-SCHEME.[16]

On graphs (fig. VIII and fig. IX) can be seen the deformation of the individual parts of the concrete slab. While in the middle of the board can see pushed into the ground, edges and corners are deformed in the opposite direction. These deformations do not symmetrical, because it is located under the plate inhomogeneous subsoil. 
On the graph on the Fig. IV and Fig. V is shown settlement of the concrete slab monitored in 6 internal sensors $(04,05,06$, 09, 20, 21 - see Fig.VI). It is clear from the graph, that settlement has substantially changed its velocity by the second test at the higher values of vertical load.

The measurement results of this (and other) plates will be compared with numerical FEM models or comparisons with other computational methods. $[9,10,11]$

\section{CONCLUSION}

As was written in the introduction: for the determination of stress in foundation structure is needed to determine the influence of the stiffness respectively pliability of subsoil to structural internal forces, and vice versa, how the stiffness of the foundation structure affects the resulting subsidence. Therefore we created On Faculty of Civil Engineering in Ostrava a test equipment just for the study of the interaction foundation and subsoil.

In this paper are presented partial result from extensive research of foundation slabs. (We measure also prestressed slabs and slabs reinforced with fiber reinforcement.)This and further tests will be used to numerical modeling interaction between foundation structure and subsoil and then used to improving existing models of this interaction. Unfortunately, the format of this article too small to described all the details of measurements and were presented all the results (eg. Comparisson with numerical models). [12,13,14,15,16]
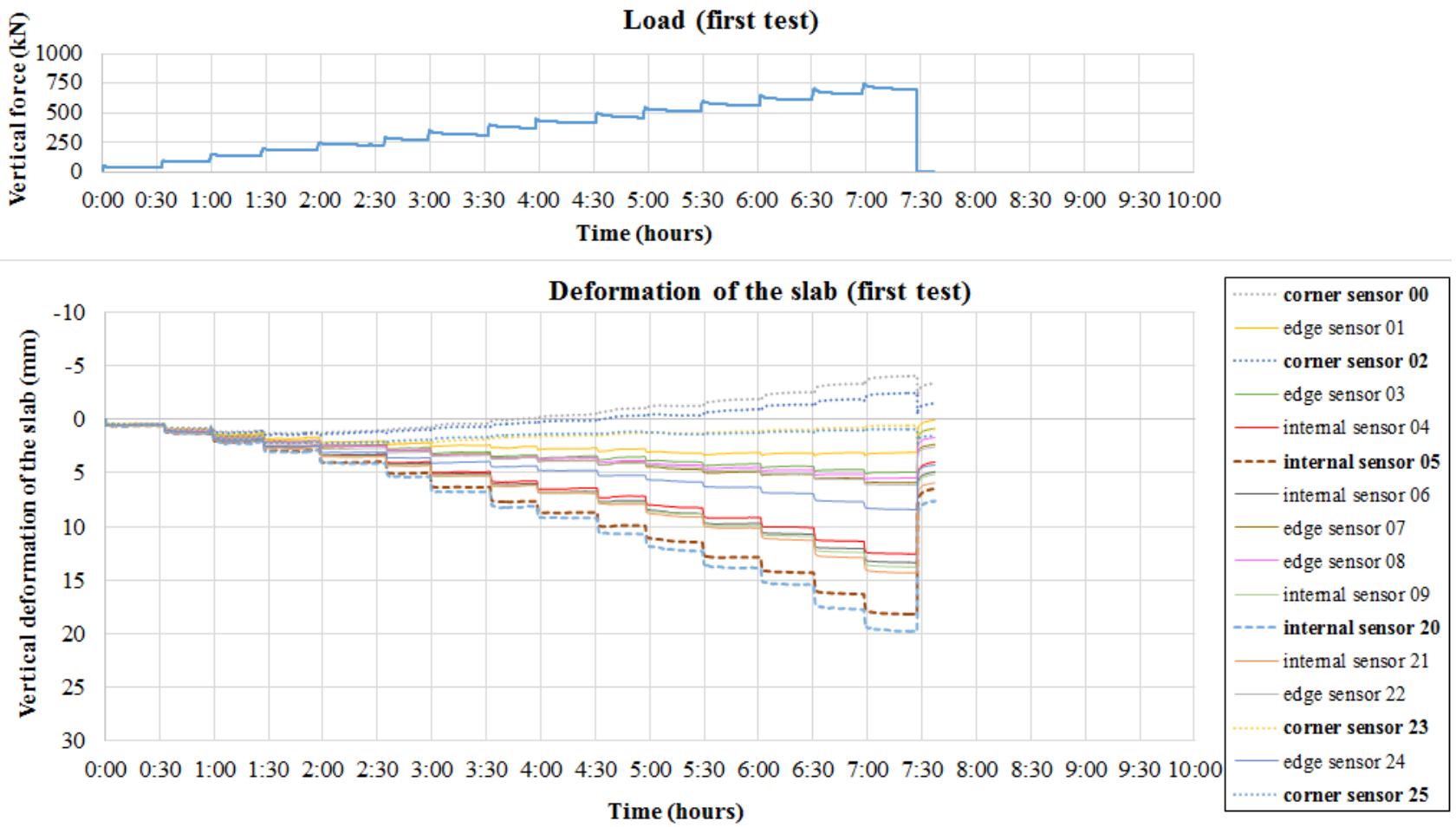

FIGURE VIII. DEFORMATION OF THE SLAB (FIRST TEST).[16]
This paper has been achieved with the financial support of the Ministry of Education, specifically by the Student Research Grant Competition of the Technical University of Ostrava under identification number SP2015/190.

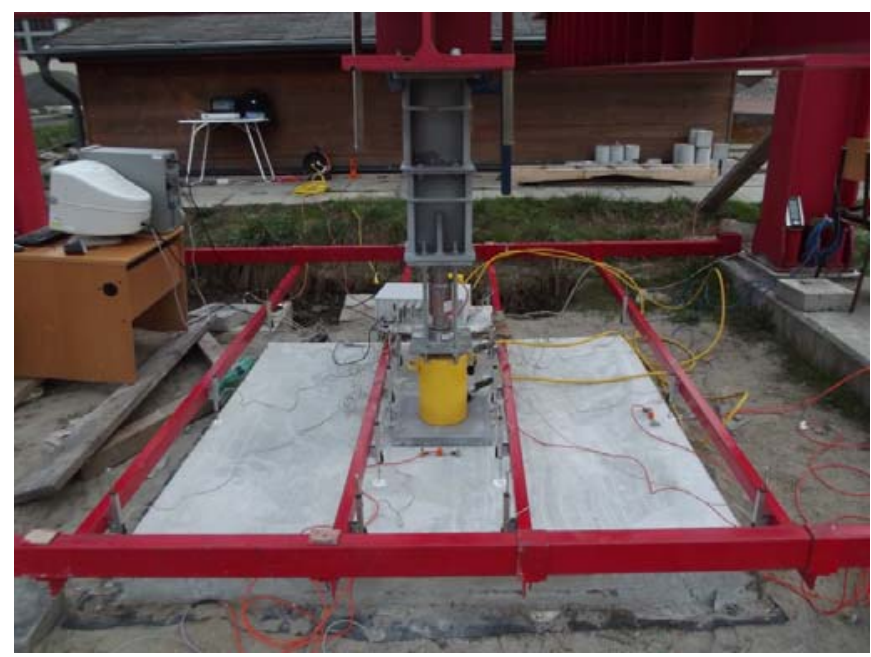

FIGURE VII. TEST ARRANGEMENTS.[16] 

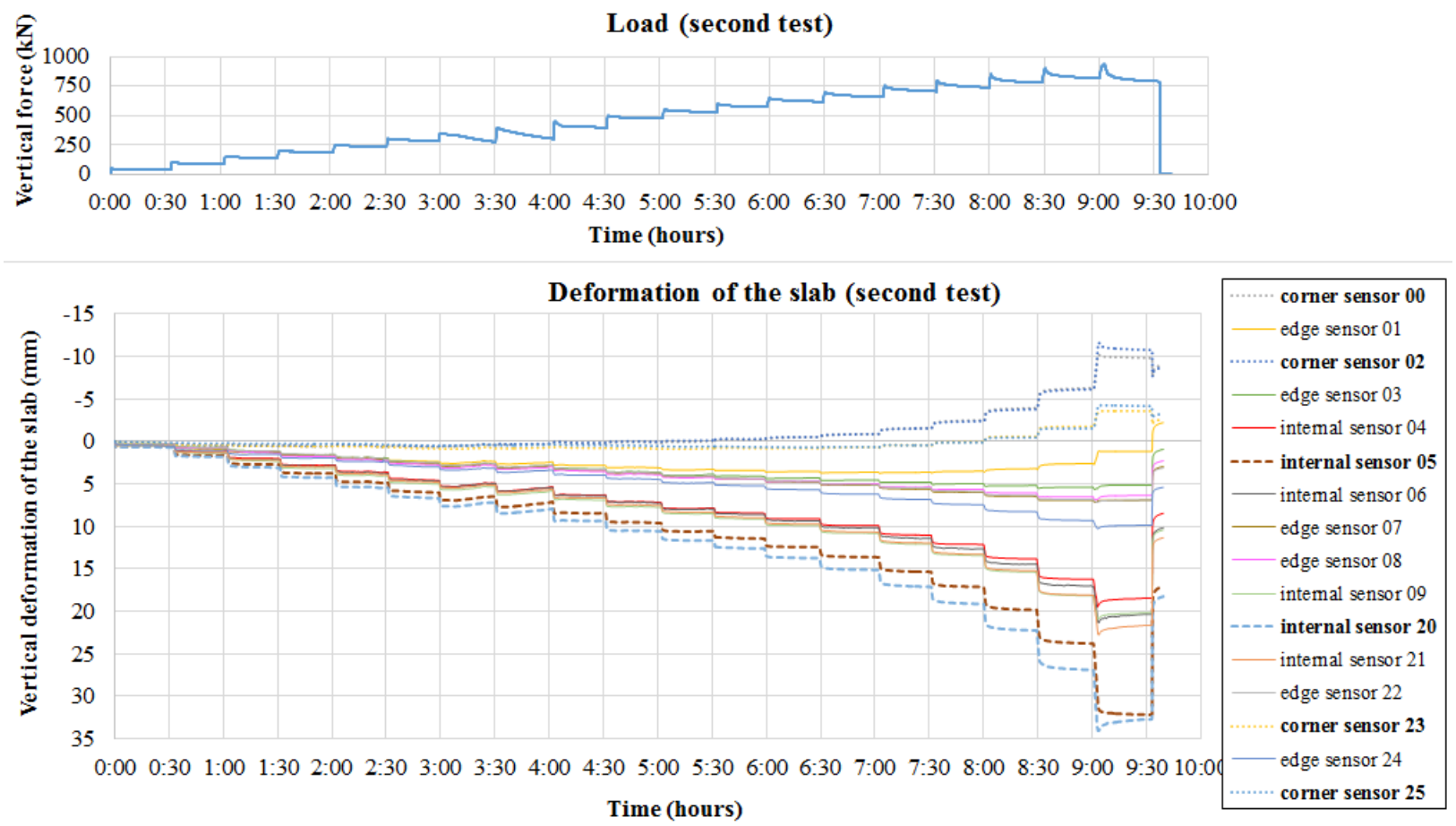

FIGURE IX. DEFORMATION OF THE SLAB (SECOND TEST).[16]

\section{REFERENCES}

[1] Kearsley, E. P., Elsaigh, W.: Effect of ductility on load-carrying capacity of steel fibre-reinforced concrete ground slabs. Journal of the South African Institute of Civil Engineering, vol. 45, No. 1, 2003. pp. 25-30.

[2] Aboutalebi, M. - Alani, A. - Rizzuto, J. - Beckett, D.: Structural behaviour and deformation patterns in loaded plain concrete groundsupported slabs. Structural Concrete. 2014, roč. 15, č. 1, s. 81-93. ISSN 1464-4177, DOI 10.1002/suco.201300043.

[3] Tiberti G., Minelli F., Plizzari G. Cracking behavior in reinforced concrete members with steel fibers: A comprehensive experimental study, Cement and Concrete Research, vol. 68, pp. 24-34 (11 p), DOI:10.1016/j.cemconres.2014.10.011, 2015.

[4] Cajka R., Burkovic K., Buchta V., Foundation Slab in Interaction with Subsoil, Advanced Materials Research, vols. 838-841, pp. 375-380 (6 p), Trans Tech Publications, Switzerland, ISSN (Online) 1662-8985, ISSN (Print) 1022-6680, DOI:10.4028/www.scientific.net/AMR.838-841.375, 2014.

[5] Mynarcik P. Measurement Processes and Destructive Testing of Fiber Concrete Foundation Slab Pattern, Advanced Material Research, vol. 1020 , pp. 221-226 (6 p), Trans Tech Publications, Switzerland, ISSN (Online) 1662-8985, ISSN (Print) 1022-6680, DOI: 10.4028/www.scientific.net/AMR.1020.221, 2014.

[6] Mynarcik P. Measurement Processes and Destructive Testing of Fiber Concrete Foundation Slab Pattern, Advanced Material Research, vol. 1020, pp. 221-226 (6 p), Trans Tech Publications, Switzerland, ISSN (Online) 1662-8985, ISSN (Print) 1022-6680, DOI: 10.4028/www.scientific.net/AMR.1020.221, 2014.

[7] CAJKA, R., MANASEK, P.: Building structures in danger of flooding. In IABSE Conference on Role of Structural Engineers Towards Reduction of Powerty, February 19-22, 2005, New Delhi, India, ISBN 978-3-85748-111-6, WOS: 000245746100072.

[8] JANUlikOVA, M., MYNARCIK, P.: Modern Sliding Joints in Foundations of Concrete and Masonry Structures, International Journal of Mechanics, vol.8, iss.1, United States: North Atlantic University Union, 2014, pp. 184 -189 (6 p), ISSN 1998-4448.

[9] CAJKA, R., KRIVY, V., SEKANINA, D.: Design and Development of a Testing Device for Experimental Measurements of Foundation Slabs on the Subsoil. In Transactions of the VSB - Technical University of Ostrava, Construction Series, Volume XI., Number 1/2011, VSB - TU Ostrava, 2011, ISSN 1804-4824 (Online). Doi: 10.2478/v10160-0110002-2.

[10] CAJKA, R.: A Subsoil Model Based on Numerical Integration of a Nonlinear Halfspace. In: Proceedings of the Eight International Conference on Engineering Computional Technology, Civil-Comp Press, Stirlingshire, UK, Paper 114, doi:10.4203/ccp.100.114, (2012)

[11] JANUlikOVA, M., CAJKA, R., MATECKOVA, P., BUCHTA, V.: Laboratory Testing of Asphalt Belts Rheological Properties Exposed to Shear Loads, Transactions of the VŠB - Technical University of Ostrava, Civil Engineering Series, vol. XII, iss. 2, pp. 59-66 (8 p), ISSN (Online) 1804-4824, ISSN (Print) 1213-1962, DOI: 10.2478/v10160-012-0018-2, January 2013.

[12] CAJKA, R., FOJTIK, R.: Development of Temperature and Stress during Foundation Slab Concreting of National Supercomputer Centre IT4, In Procedia Engineering, Volume 65, 2013, Pages 230-235, ISSN 1877-7058, doi: 10.1016/j.proeng.2013.09.035.

[13] CAJKA, R., BUCHTA, V., BURKOVIC, K., FOJTIK, R.: Experimental Testing and Numerical Modelling of Foundation Slab in Interaction with Subsoil. In Fib Symposium Tel Aviv 2013, Technology Modeling \&

[14] Construction, Page 209-212, Tel Aviv, Israel, April 22-24, 2013, ISBN 978-965-92039-0-1

[15] BUCHTA, V., MYNARCIK, P.: Experimental testing of fiberconcrete foundation slab model, Applied Mechanics and Materials, vols. 501 504, pp. 291-294 (4 p), Trans Tech Publications, Switzerland, ISSN (Online) 1662-7482, ISSN (Print) 1660-9336, DOI:10.4028/www.scientific.net/AMM.501-504.291, 2014.

[16] BUCHTA, V., JANULIKOVA, M., FOJTIK, R.: Experimental Tests of Reinforced Concrete Foundation Slab. Procedia Engineering. Vol.114: 530-537. ISSN 18777058, DOI: 10.1016/j.proeng.2015.08.102., 2015 